\title{
Use of renewable energy for desalination in urban agriculture in the GCC countries: Possibilities and challenges
}

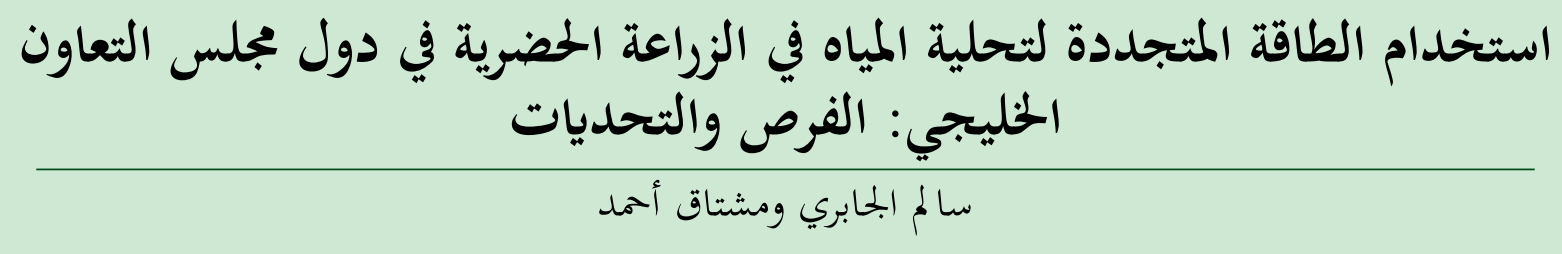

AbstraCt. The current dependence of the GCC countries on fossil oil and gas is unwise in terms of economic and environmental sustainability. GCC countries must consider the use of renewable energy to cope with price fluctuations of oil and gas in the global market and to lower the emission of green house gases. The demand for food and water in the GCC countriesis increasing due to high growth rate of population. Given the weather conditions and available amounts of natural water resources, the demand on food and water cannot be met unless alternative sources of water are considered. Several studies pointed out that the desalination technology is probably the only option for producing ample amounts of water for food production in arid environments. This work explores the potential of use of desalination technology for producing irrigation water in GCC countries, with special emphasis on experience of the Sultanate of Oman compared with that of Spain. Desalination can always provide a tailored-quality irrigation water at any climatic conditions. The main challenge for considering desalination for agriculture is purely economic; where GCC countries could consider it only if intensive horticulture of high-value cash crops, such as vegetables and flowers in controlled environments, is considered. Disposal of brine water is also a challenge and must be done at an additional cost. Depending on the quality of desalinated water, several studies showed that solar-operated desalination technologies are in a mature stage and economically viable. Therefore, solar energy can make the desalination technology an attractive option to sustain agriculture and food supply in GCC countries.

KEYWORDS: Desalination; renewable energy; urban agriculture; irrigation; brine disposal.

الملحص: إنعتمد دول بحلس التعاون الخليجي حالياً على النفط الأحفوري والغاز في توفير الطاقة اللازمة للتنمية عموماً ولتحلية المياه خصوصاً.

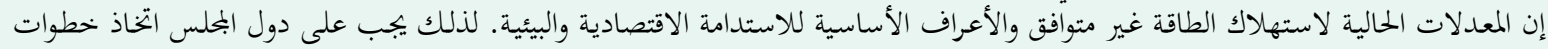

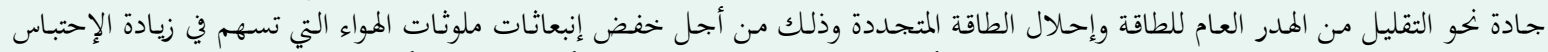

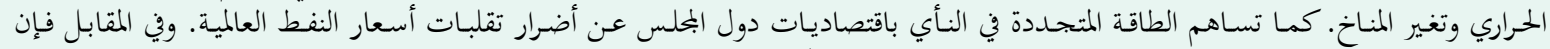

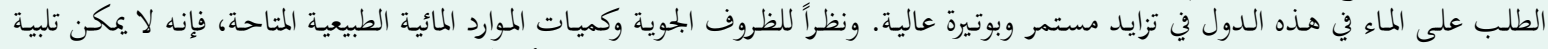

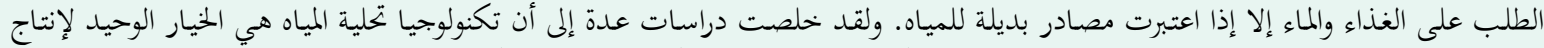

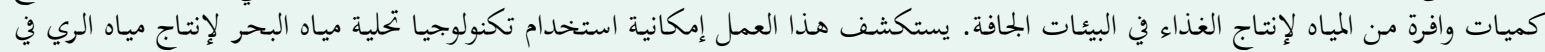

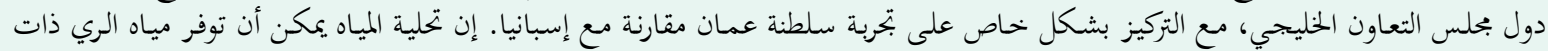

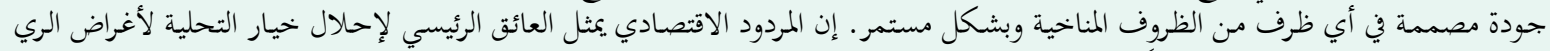

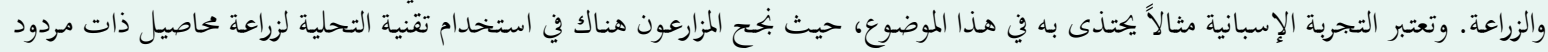

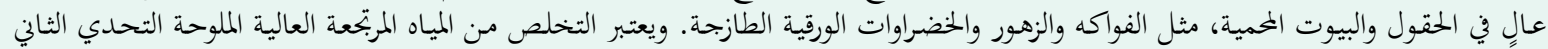

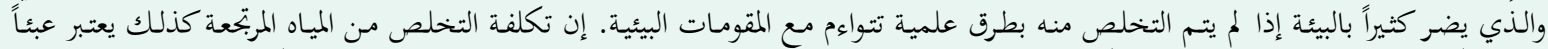

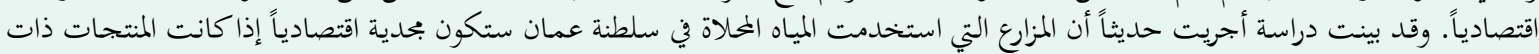

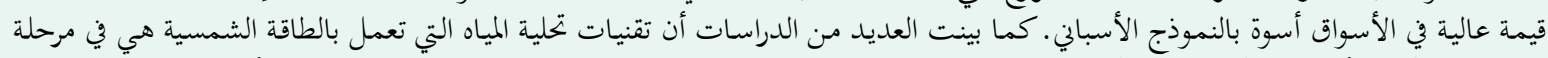

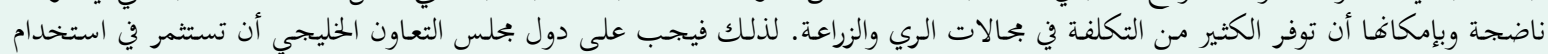

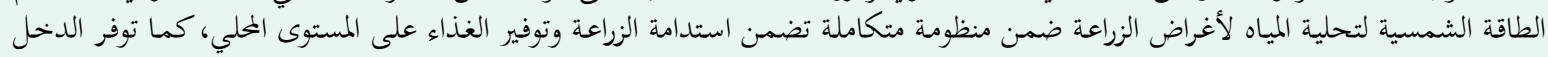

$$
\text { المناسب للمزارع في ظل ظروف لئية لمياه لاغراضية مناسبة. }
$$

الكلمات المفتاحية: تحلية المياه، الطاقة الشمسية، الزراعة، الاستدامة

\section{Introduction}

"Salem Al-Jabri ( Sultan Qaboos University, College of Agricultural and Marine Sciences, Dpt. of Soils, Water and Agricultural Engineering. Box 34, Al-Khod 123. Sultanate of Oman. Email: salemj@squ.edu.om
7 he Gulf Cooperation Council (GCC) was established in 1981 with six member countries: Bahrain (BH), Kingdom of Saudi Arabia (KSA), Kuwait (KW), Sultanate of Oman (OM), Qatar (QR), and United Arab Emirates (UAE). Historically, the geographical location of the Arabian Gulf provided a focal 
significance to the GGC members, especially with the discovery of oil and gas reserves after World War II. Since then, the GCC members experienced a dramatic change in general lifestyle and became the pivotal centre for energy at the global market. The GCC countries own $33.1 \%$ of oil reserves, the world's largest, and $20.8 \%$ of the global reserves of the natural gas. Consequently, GCC members became a centre of development and many expatriates and cooperants started to dwell in the region for business opportunities, which caused the region to also have one of the highest population growth rate in the world (Oxford Economics, 2015). Figure 1 presents the trend of population growth in the GCC for the period 1995-2014 (GCC statistical bulletin, 2016), which implies the population has doubled in just less than 20 years. Expatiates are becoming a high proportion of the overall population of the GCC countries when compared with their local citizens. For example, expatriates represent about $33 \%$ and $85 \%$ of total population of KSA and UAE, respectively (GCC statistical bulletin, 2016). Most of these expatriates are of low skills and, due to their educational level and native culture, pay little attention to water scarcity, among other natural resources.

\section{Energy consumption in GCC}

Energy requirements in the GCC have increased dramatically due to a rapid increase in development of infrastructure and population growth and due to improvement of lifestyle standards and hygiene. Figure 2 indicates that GCC countries are spending staggering amounts of energy to generate electricity for various reasons, but mainly for water desalination. Even though energy saving may look unnecessary, the GCC countries must undertake practical steps to reduce energy consumption in order to increase efficiency and reduce emissions of greenhouse gases. Energy-related challenges that face the GCC members are fluctuations of international oil prices, the emergence of new export competitors, the discovery of shale oil and gas in some countries, and subsidy programs for energy and water at the national level. Moreover, some GCC countries are facing constraints in gas production capacity that force them to import it from neighboring members or Iran.

Table 1. Water resources reserves in the GCC countries.

\begin{tabular}{|c|c|c|c|c|}
\hline Country & Area $\left(\mathbf{k m}^{2}\right)$ & $\begin{array}{l}\text { Mean annual } \\
\text { rainfall }(\mathrm{mm})\end{array}$ & $\begin{array}{c}\text { Groundwater recharge } \\
\qquad\left(\mathrm{Mm}^{3} \mathrm{y}^{-1}\right)\end{array}$ & $\begin{array}{c}\text { Non-renewable reserves } \\
\left(\mathrm{Mm}^{3}\right)\end{array}$ \\
\hline Bahrain & 652 & $30-140$ & 110 & negligible \\
\hline Kuwait & 17818 & $30-140$ & 160 & $\mathrm{n} / \mathrm{a}$ \\
\hline Oman & 300000 & $80-400$ & 900 & 102000 \\
\hline Qatar & 11610 & $20-150$ & 50 & negligible \\
\hline Saudi Arabia & 2149690 & $30-550$ & 3850 & 428400 \\
\hline UAE & 83600 & $80-160$ & 190 & $\mathrm{n} / \mathrm{a}$ \\
\hline
\end{tabular}

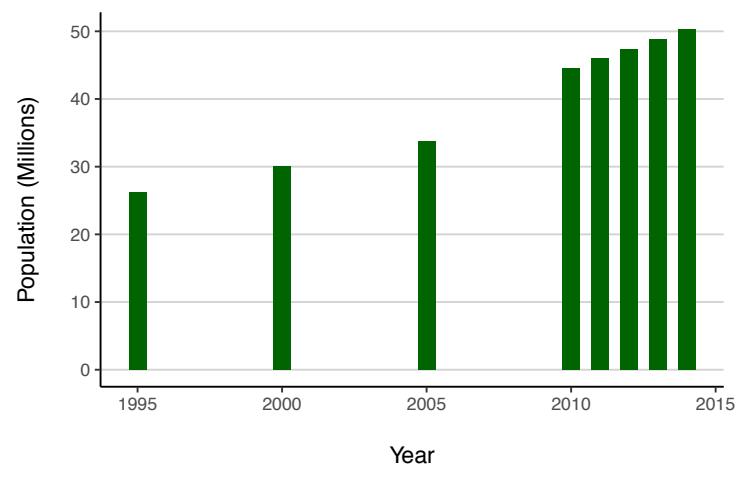

Figure 1. Total population (millions) of GCC countries between 1995 and 2014. Source: GCC statistical bulletin (April, 2016).

Therefore, they must invest in new technologies to enhance their gas production rather than depending on the imports (Economist Intelligence Unit, 2010). The proceeding implies that GCC countries should, therefore, undertake firm measures towards energy sustainability through (i) introducing energy-efficiency measures; (ii) investing in clean fuel and renewable energy supplies; (iii) improving water efficiency; and (iv) investing in new water desalination capacity.

\section{Water status in the GCC countries}

The GCC members are classified as arid countries and characterized by low and erratic rainfall rates, limited groundwater reserves, high evapotranspiration rates (about $3000 \mathrm{~mm}$ per year), and low recharge rates for groundwater aquifers. Moreover, the increase in global warming due to greenhouse emissions and climate change worsen the situation in the region and results in prolonged periods of droughts. The Intergovernmental Panel on Climate Change (IPCC 2007a; 2007b; 2014) predicted that the region will face some environmental stresses due to the increase in gas emissions, which may include high incidence of reduced flows, declines in rainfall, and higher temperatures. Table 1 lists some important figures regarding the hydrologic cycle in the GCC countries (World Bank, 2005). Highlights from

Source: World Bank (2005). 


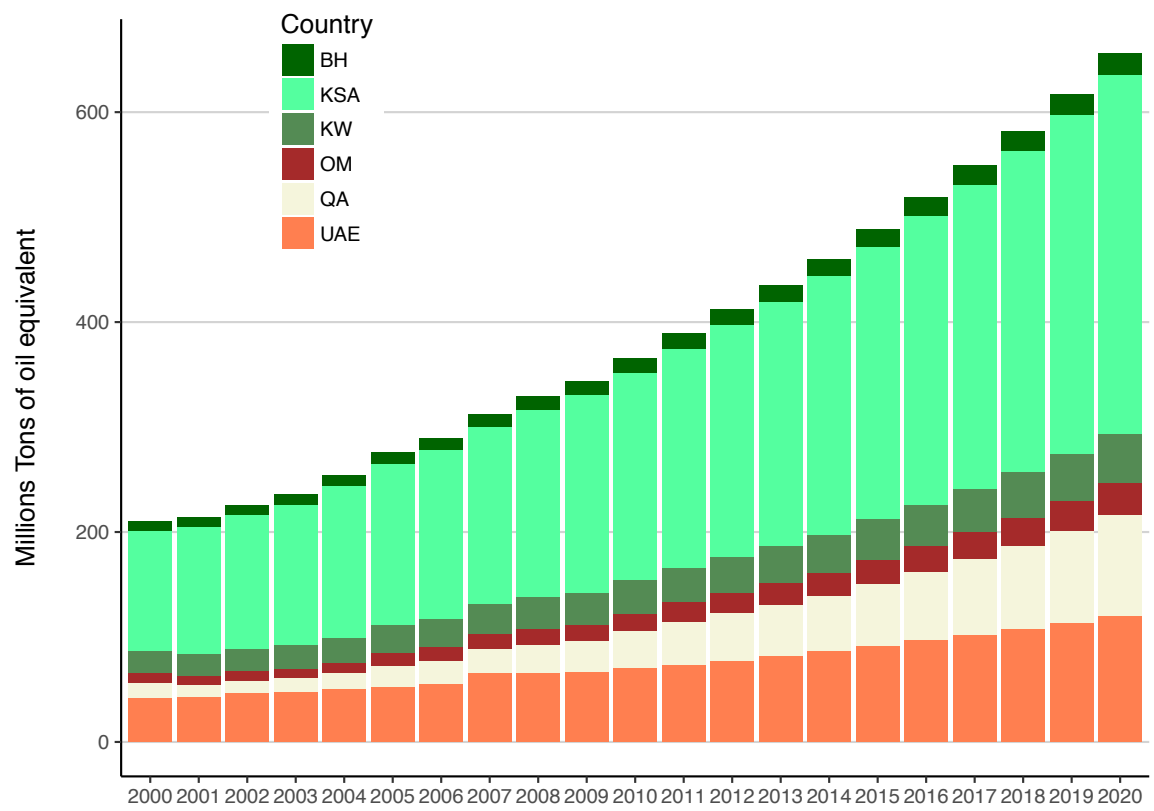

Figure 2. Total energy consumption (millions tons of oil equivalent), for GCC countries between 2000 and 2020. Data for 2005-2007 are actual; for 2008-2010 are estimated; and for 2011-2020 are forecasted. Source: Economist Intelligence Unit (2009).

table 1 are the erratic rainfall rates and low annual recharge water rates. This situation made GCC countries not consider groundwater reserves as a strategic source for drinking water. GCC members are currently considering desalination as the sole source for drinking water.

Ironically, GCC countries are considered one of the highest per-capita users of water in the world. Ahmed et al. (2016) pointed that the GCC countries consume relatively more water than the world's average and is estimated at $816 \mathrm{~m}^{3} /$ capita-year. The world's average is estimated at $500 \mathrm{~m}^{3} /$ capita-year, (PwC, 2014). With such limited resources, the per capita of water has declined over the period 1970-2012 (Fig. 3). Obviously, this is due to the increase of population, water-intensive lifestyle, and high abstraction rates from groundwater aquifers (which are much greater than recharge rates).

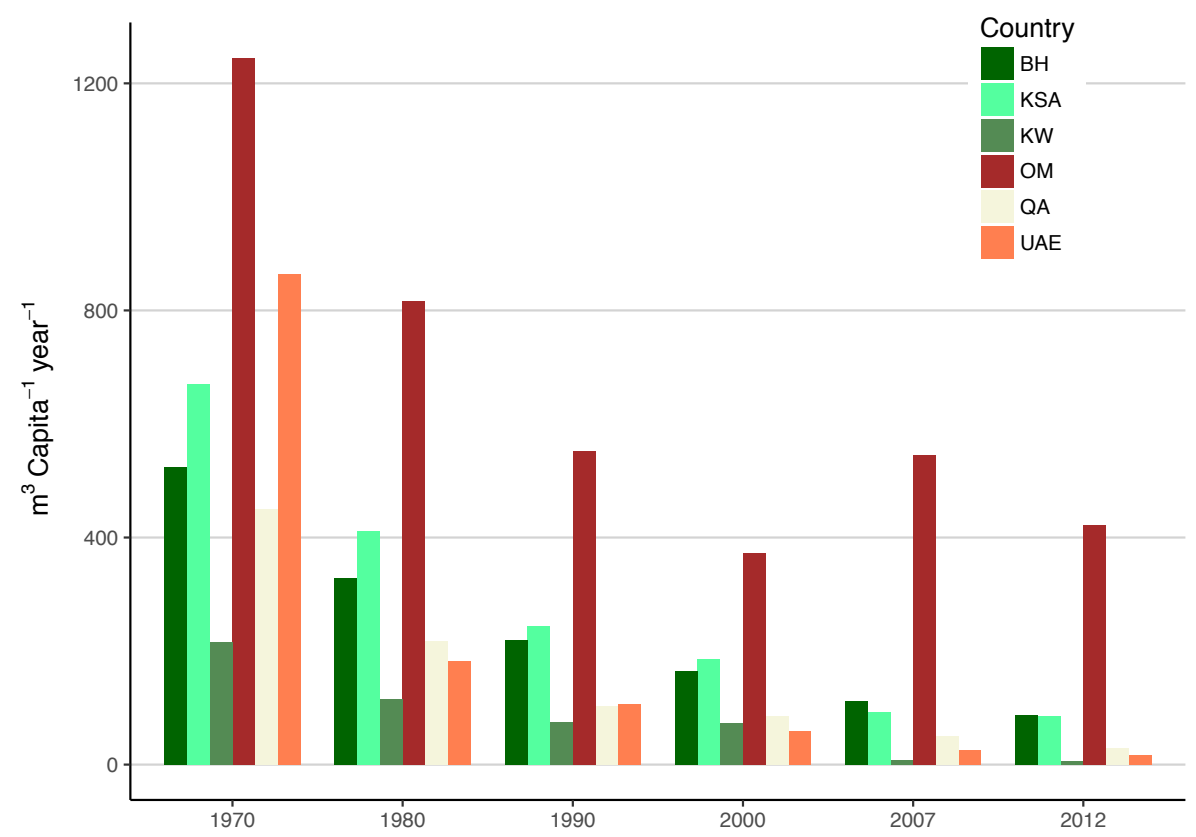

Figure 3. Changes of annual renewable water per capita between 1970 and 2012 for the GCC countries. Source: World Bank (2005). 


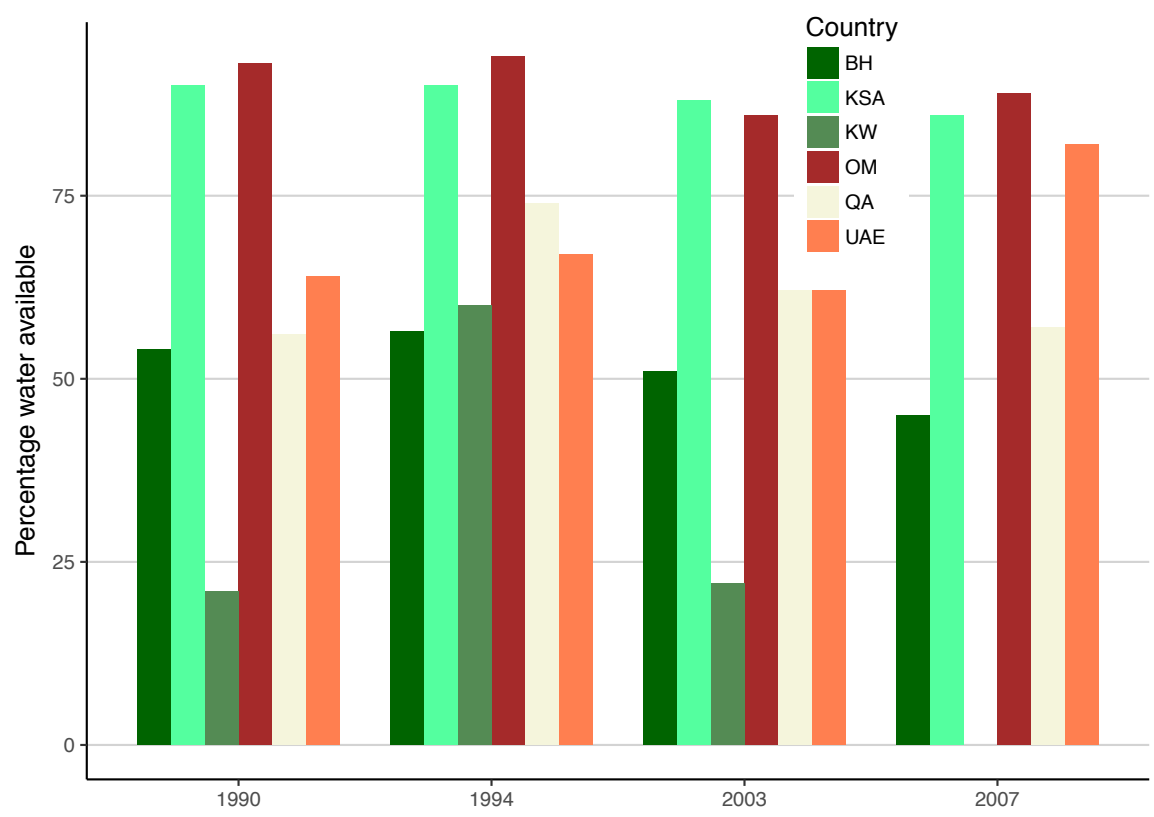

Figure 4. Agricultural use of water in GCC countries as percent of total consumption, 1990-2007. Data for Kuwait(KW) in 2007 is missing. Source: World Bank (2005).

Despite the low contribution towards GCC's national GDP $(<5 \%)$, the agricultural sector consumes most of the water resources available annually (Fig. 4). The GCC countries are aware of the upcoming competition in the energy market and that oil and gas probably will not last forever. Therefore, given the current status of water in the GCC countries and the concerns regarding climate change related to the oil and gas industry, proactive and innovative approaches should be considered to reduce the dependency on oil and gas as sources of energy, and find alternative sources of water to reduce pressure on finite groundwater resources. Based on the recent review of literature, we are suggesting considering desalination technology for providing irrigation water for growing value crops for sustaining agriculture and fresh food supplies in the GCC countries and reduce the demand on finite groundwater resources, while sustaining the environment. This work reviews the international experience of the world for using desalination for agriculture. It highlights the opportunities, challenges, and the environmental risks of considering desalination technologies for agriculture in the GCC countries. Moreover, we are presenting an example for the use of the technology for producing irrigation water from $\mathrm{Al}$ Batinah coast in the Sultanate of Oman. We are exploring the use of renewable energies to operate desalination facilities in order to minimize the desalination costs and environmental risks. Finally, concluding remarks on the overall use of desalination technology are presented.

\section{Desalination for agriculture: op- portunities and challenges}

Over abstraction of groundwater in GCC is much higher than rates of recharge from erratic and low rainfalls. Over abstraction resulted in drop of groundwater levels to critical levels that resulted in many environmental and social issues. In coastal aquifers of Oman, for example, groundwater dropped to levels below the static seawater level, which caused an imbalance of water pressures between sea level and those at the coastal aquifers. This, in turn, caused seawater to contaminate the coastal aquifers of Al Batinah, the most extensive agricultural region in the country (Zekri, 2009). Farmers have no source of water except groundwater and, therefore, rich agricultural soils were spoiled by saline irrigation water (Al-Belushi 2003; Bajjali 2003; Al Barwani and Helmi 2006; Choudri et al. 2013). The salinization of agricultural soils is a huge loss to the farmers in terms of (i) deterioration of soil quality, (ii) loss of crop yields due to salinity stresses, and (iii) growing salt-tolerant crops of low economic returns. This situation suggests considering alternative sources of water in conjunction with innovative techniques for water management for the sake of sustaining agriculture in GCC countries, especially at coastal cities. Al Khamisi et al. (2013) suggested using treated wastewater (TWW) in conjunction with groundwater for irrigation in efforts to minimize groundwater abstraction and enhance hydrostatic pressures of coastal aquifers of Al Batinah (Oman). However, this option cannot be economically feasible when costs of transportation and distribution networks are added to the overall value of irrigation water. Moreover, Al 


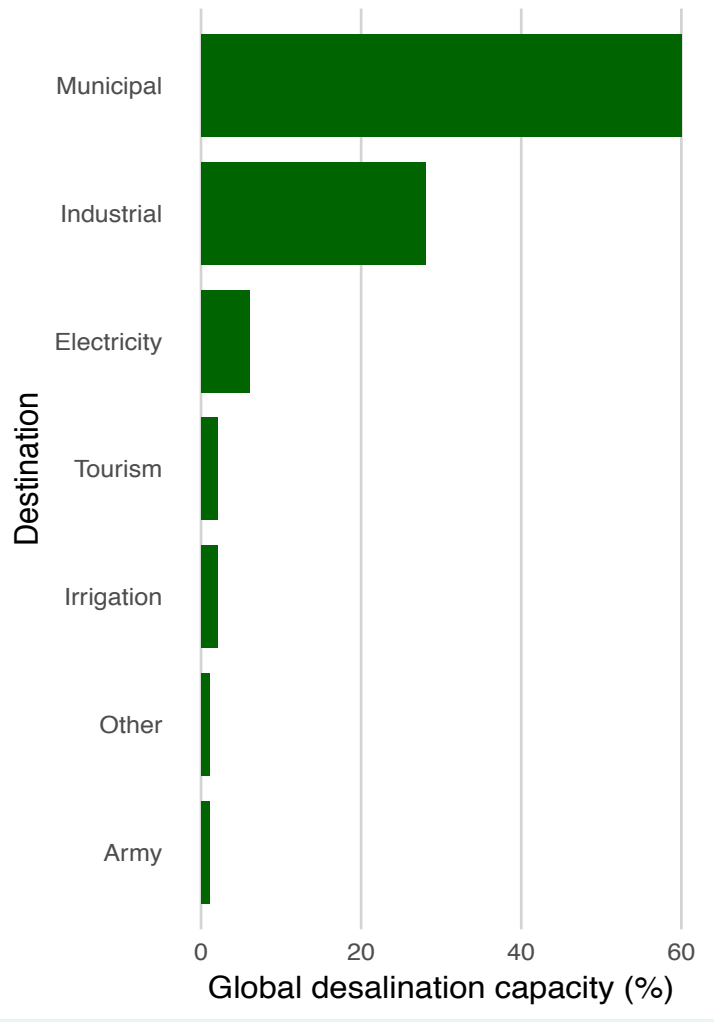

Figure 5. Global desalination capacities by sector (Burn et al., 2015).

Jabri et al. (2012) explored the option of injecting surplus TWW into coastal aquifers to reduce the extent of seawater intrusion. However, artificial recharge using TWW is costly and only a small fraction of injected water could be recovered (Bouwer, 2002). The quality of recharging water could lead to changes in physical and chemical characteristics of the soil and aquifer. Some impurities, such as microbes, heavy metals or trace elements, if present in recharging water will contaminate the aquifer, and will be very expensive to contain and clean (Bouwer, 2002). Elimelech and Philip (2011) identified desalination of sea and brackish waters is the only practical option to provide water in ample amounts beyond the hydrologic cycle in arid environments. Due to advancement in desalination technology, Lattermann et al. (2010) argued that the costs of wastewater treatment and desalination are likely to be similar in 2015 and beyond, especially in the US.

\section{World's experience on desalination for agricul- ture}

Many countries are utilizing desalination technology as a source for irrigation water. Spain is the leading country in the world, where $22 \%$ of its desalination capacity (14 million $\mathrm{m}^{3} /$ day) goes for irrigating high value crops (Zarzo et al., 2012). Examples of crops grown in Spain with desalinated water are fresh vegetables, fruits, toma- toes, pepper, watermelons, oranges, and table grapes. Kuwait uses about $13 \%$ of its desalination capacity (1 million $\mathrm{m}^{3}$ /day) for agriculture (Burn et al., 2015). Saudi Arabia, the world's largest single producer of desalinated water, utilizes only $0.5 \%$ of its desalination capacity for agriculture. Other countries, such as Italy, Australia, China, Chile, Qatar, Bahrain, and USA are using desalinated water for agriculture at varying amounts. Figure 5 shows that only $2 \%$ of global desalinated water is used for agricultural purposes (adapted from Burn et al., 2015). Farmers in Al Batinah, and other coastal areas in Oman, are starting to use small-size desalination units to produce good-quality irrigation water for their farms (Al Jabri et al., 2015).

\section{Opportunities and challenges of adopting de- salination for agriculture}

Desalination for agriculture has many advantages as identified by Burn et al. (2015):

- $\quad$ tailored quality for irrigation;

- $\quad$ assured supply;

- enables agricultural products of consistent quality;

- $\quad$ production may be increased compared with other sources of water;

- desalinated water may achieve a higher resale price due to quality and supply assurance; and

- desalinated water, i.e. good-quality water, allows recovery of saline soils.

The choice of desalination technology is influenced by the quality of intake water, cost of energy, energy demand, and value of desalinated water. The adoption of desalination technologies to produce irrigation water has many challenges. The main challenge is economic: desalination is still an expensive option for agriculture. This is because the size of a desalination unit is relatively small, which implies water is produced at high cost. Energy-efficient desalination technologies will make this option an appropriate one for providing irrigation water. Moreover, desalination costs can be reduced by using more efficient irrigation systems and intensifying agriculture of high-value crops. Due to the advancement of desalination and filtration technologies, the current cost of desalination is only about $1 / 6$ of that in 1970 s (FAO, 2003).

Another challenge to desalination of agriculture is environmental: the amount and disposal means of brine discharge. The desalination process using reverse osmosis (RO) technology produces brines at about $60 \%$ of feed water volume at almost twice the salinity level of the intake water (FAO, 2003). Therefore, inland desalination is hindered by means of brine disposal and adds an additional cost. However, high recovery of desalinated water is available with new technologies, such as mem- 
Table 2. Characteristics of some desalination units used at farm level in Oman.

$\begin{array}{lccc} & & \text { Model of desalination unit } & \text { Large } \\ & \text { Small } & \text { Medium } & 38.0 \\ \text { Production capacity }\left(\mathrm{m}^{3} / \text { day }\right) & 11.5 & 19.0 & 6,000 \\ \text { Cost of the unit (OMR) } & 3,000 & 4,500 & 600 \\ \text { O \& M (OMR) } & 420 & 480 & 3.5 \\ \text { Energy requirements }\left(\mathrm{kWh} / \mathrm{m}^{3}\right) & 2.7 & 3.0 & \end{array}$

brane distillation, which should reduce disposal costs per unit of water produced (Burn et al., 2015). Ahmed et al. (2002) discussed brine disposal in Oman. However, there is no work conducted in the GCC countries regarding inland disposal of brines from desalination units for agriculture. Brine disposal in the ocean requires a given dilution ratio set by environmental agencies at a given country.

The quality of desalinated water usually meets irrigation requirements in terms of total dissolved salts (TDS) with an electrical-conductivity (EC) value of 0.2-0.3 $\mathrm{dS} / \mathrm{m}$. Depending on the source of feed water, however, caution must be taken when it comes to the level of boron (B) and TDS in desalinated water. The B-concentration in irrigation water should be less than $0.50 \mathrm{mg} / \mathrm{L}$, TDS of less than $450 \mathrm{mg} / \mathrm{L}$, and chloride concentration of less than $105 \mathrm{mg} / \mathrm{L}$ (Shaffer et al., 2012). Boron in neutral and acidic environments passes through the RO filters and its concentration may reach $2.0 \mathrm{mg} / \mathrm{L}$, which is very toxic to many fruits and vegetables. Zarzo (2012) listed some crops that are "semi-tolerant" to B concentration of $1.0 \mathrm{mg} / \mathrm{L}$. Special filters are needed to remove extra B, which means extra cost is need to added to the desalination costs. Another issue with desalination processes is the removal of divalent cations; such as calcium, magnesium, and sulfates. These cations stabilize the structure of agricultural soils and are plant nutrients. This means re-mineralization of desalinated water is needed and can be done at an extra cost to the process of desalination.

\section{Extent of desalination for agriculture in GCC: Oman as an example}

Al Jabri et al. (2015) explored the use of desalination in the Al Batinah coast with the following indicators (i) cost of desalination unit, (ii) operation and maintenance costs (O\&M), (iii) purpose of desalination, (iv) amounts and quality of desalinated and reject brines, (v) means of disposal of brines, and (vi) types of crops grown. Table 3 summarizes cost and energy requirements of the desalination units used in the coastal farms in Al Batinah. All units used are based on the RO technology. Energy tariffs in Oman are subsidized and are in the range of Riyal Omani (OMR) 0.01-0.025 per kWh. Most units shown are assembled locally from imported parts. Imported whole units are also available in Oman and neighboring UAE. Table 4 lists some chemical properties of intake, desalinated, and brine waters and means of brine disposal. Desalinated water produced meets irrigation requirements. Most visited farms did not have greenhouses and desalinated water is used to irrigate date palms and field vegetables and other crops. This implies that farmers are not considering the economics and profitability issues here. The other issue is how do farmers dispose the high saline brine water. Obviously, farmers are not aware of the environmental impacts of dumping this water in soil pits and old wells. Brine water immediately destroys the structure of the soil and contaminates immediate aquifers. The deterioration of soil structure causes low infiltration capacities and, therefore, brine water remains stagnant over soil surface for prolonged periods of time. Some farmers stop operating desalination units and, hence stop irrigating, until stagnant water disappears from the soil's surface or wells. Farmers are considering brine disposal is the only barrier for them to use desalination units at their farms in $\mathrm{Al}$ Batinah coast (personal communication).

\section{Economics of desalination for agriculture in $\mathrm{Al}$ Batinah coast in Oman}

Farmers in Oman pay 10 Baisas $(\mathrm{Bz})$ per $\mathrm{kWh}$ (0.01 OMR/kWh), while the cost of electricity generation is $25 \mathrm{Bz}$. Once the distribution infrastructure is added, the total cost of electricity including is estimated at $50 \mathrm{Bz} / \mathrm{kWh}$. Al-Jabri et al. (2015) presented an analysis on the real cost of desalination for the farmers in Al Batinah. Water used for desalination in Oman is brackish

Table 3. Chemical properties of intake, desalinated, and brine water and means of brine disposal.

$\begin{array}{rcccc} & \text { Intake water } & \begin{array}{c}\text { Desalinated } \\ \text { water }\end{array} & \text { Brine } & \text { Means of brine disposal } \\ \text { Electrical Conductivity }\left(\mathrm{dS} \mathrm{m}{ }^{-1}\right) & 8.09 & 0.36 & 25.6 & \text { Soil pits, soil surface, old wells } \\ \mathrm{pH} & 7.2 & 7.1 & 7.31 & \text { Areas outside the farm }\end{array}$




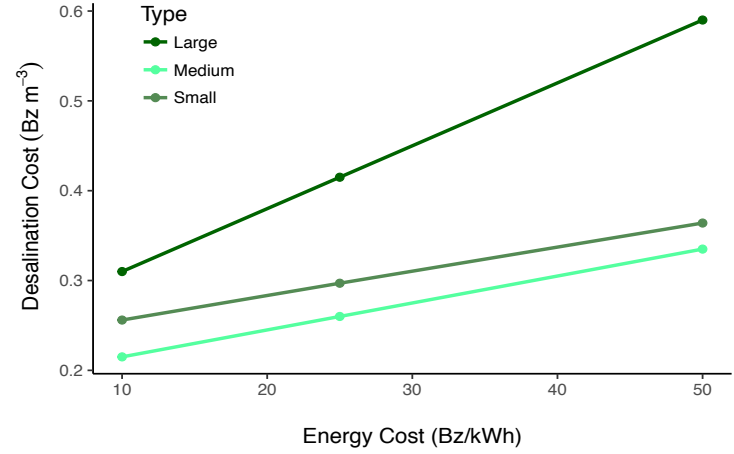

Figure 6. Cost of desalination (1 Baiza: $\mathrm{Bz}=0.001 \mathrm{OR}$ ) of brackish water $\left(10 \mathrm{~g} \cdot \mathrm{L}^{-1}\right)$ in the Sultanate of Oman for agriculture.

with total dissolved salts (TDS) of about $10000 \mathrm{mg} / \mathrm{L}$. The life span of desalination units in Oman is about 10 years (personal communications). Assuming an interest rate of $12 \%$ (common in Oman for small loans) and 10yr life span, the total cost of desalination to the farmer varies from 215 to $310 \mathrm{Bz} / \mathrm{m}^{3}$ (Fig. 6). The difference between what the farmers pay and the real cost of energy is indirect subsidy. Therefore, the farmers can make a profit at the current subsidized energy prices on the conditions of growing high-value crops. The FAO (2006) report described the economic conditions at which farmers can make profit by using desalination technology in Oman. They should grow high-return crops; such as peppers, eggplants, cucumbers, onions, okra, carrots, cherry tomatoes, strawberry, and capsicums. It should be noted here that the FAO (2006) report has not included the cost of brine disposal in this analysis.

\section{Renewable energy for desalination for agriculture}

The global trend in energy market is to reduce energy demand through development of more energy-efficient technologies and finding substitutes for the fossil fuel. The GCC countries are aware of the world's increased competition in energy market and must be ready for the future. They must look for alternative sources of energy due to ever increasing demand for fresh water and energy in the Gulf. In the meantime, they must work on developing technologies that utilize renewable sources of energy to sustain the environment and reduce the demand on energy and finite groundwater. Technologies that are based on renewable sources of energies, such as wind, solar, geothermal; can be greatly utilized for water desalination (Serpen et al., 2010; Goosen et al, 2010). Coupling renewable energies with desalination systems has a great environmental and industrial potentials in water-scarce countries (Mahmoudi et al., 2008, 2010;
Goosen and Shayya, 1999). The effective integration of a source of renewable energy with a desalination system will allow GCC countries to address water shortage at city levels without any impact on air pollution and global warming due to climate change. Furthermore, this approach will help bypass the problems of rising fuel prices and decreasing fossil fuel supplies (Goosen et al., 2011). This section discusses the opportunities and challenges of utilizing solar energy for desalination of water to grow vegetable crops in urban cities for sustaining natural environment and water resources.

\section{Solar energy for water desalination}

Renewable energies for use in desalination processes include wind, solar thermal, photovoltaic and geothermal. Renewable energy that operate the desalination systems are categorized into: (i) those which include distillation processes driven by heat produced directly by the renewable energy system (RES), and (ii) those which include membrane and distillation processes driven by electricity or mechanical energy produced by RES. Solar energy can be used to desalinate brackish water in remote areas or areas that require small amounts of water on daily basis (Al-Hallaj et al., 1998). Solar energy can be used directly as thermal or can be converted into electrical energy to drive desalination units that are based on reverse osmosis. Thermal energy can be used with solar ponds or collectors. Photo-voltaic cells are used to convert solar energy into electricity. Solar thermal power plant is another choice for this conversion.

\section{Solar stills and solar ponds for desalination}

Goosen et al. (2000) discussed thoroughly the use of solar stills for water distillation (Fig. 1 therein). It can be used where the demand is low and enough land is available. It is used to produce small amounts of fresh water. Solar stills can be extended to improve the performance and amounts of water produced (Goosen et al., 2000). Solar ponds combine solar energy collection with longterm storage (Goosen et al., 2011). A solar pond stores energy by having a salt concentration gradient in the pond. Water surface at the pond has an ambient temperature. However, the bottom of the pond, where the salt concentration is highest, is much higher temperature (about $90^{\circ} \mathrm{C}$ ). The temperature difference is large enough, where the heat is used to generate energy for desalination (Fig. 2b of Goosen et al., 2011) or to drive the vapor generator of an organic Rankine cycle engine (Wright, 1982). Solar ponds have a rather large storage capacity, which allows seasonal as well as diurnal thermal energy storage (Goosen et al., 2000).

\section{Solar photovoltaic (PV) systems for desalina- tion}

Solar panels directly convert solar energy into electrical energy via solar cells (Kalogirou, 2005). Solar cells are made from semiconductor materials such as silicon 
and are connected with other cells to form a PV module. Any number of PV modules can be combined to form an array, which will supply the power required by the load (Kalogirou, 2005). Energy storage equipment (batteries) and necessary accessories, such as charge controllers and inverters, are needed to store energy and convert direct current form PV cells to alternating current. The life expectancy of the system can be up to 30 years. Desalination units, based on reverse osmosis (RO) or electrodialysis (ED), that utilize solar energy are mature technologies and readily available in the market. The feasibility of PV-powered RO or ED systems, as valid options for desalination at remote sites, has also been proven (Childs et al., 1999). The main problem of these technologies is the high cost and, for the time being, the availability of PV cells.

Goosen et al. (2011) cites several studies that compare the use of solar energy with different desalination methods, such as thermal and distillation technologies. They conclude that all solar-driven desalination can be used for small-scale water production, except probably for PV-RO technology. A patented direct drive engine (DDE) converts heat to the hydraulic power required by $\mathrm{RO}$ is projected to be more than three times greater than that which would be obtained by RO driven by a dish Stirling electricity generation system or PV power (Goosen et al., 2011). Burgess and Lovegrove (2005) noted that the project becomes less attractive due to the advances in conventional RO. The choice of the RO desalination plant capacity depends on the daily and seasonal variations in solar radiation levels, on the buying and selling prices for electricity, and on the weight giv- en to fossil fuel displacement (Burgess and Lovegrove , 2005). A conceptual layout for a solar dish based system with power generation and $\mathrm{RO}$ desalination is shown in (Fig. 7).

\section{Conclusion}

Substantial amounts of oil and gas are used in the process of desalination in the GCC countries, which produces huge amounts of emissions that significantly contribute to global warming and climate change. Sources of renewable energy for desalinating sea and brackish water in urban cities in the GCC must be utilized to meet increasing demand on water for food production and reduce gas emissions. Given the weather conditions and amounts of natural water resources in GCC region, desalination is probably the only choice for providing substantial amounts of water for irrigation at any time with a tailored quality. Economic and environmental issues are the constraints for adapting desalination technologies for agricultural purposes. Economic constraints can be greatly reduced with solar-operated reverse-osmosis units in conjunction with intensive agriculture of high-value horticultural crops. Environmental constraints are alleviated with safe disposal of brines into the sea, or through evaporation ponds. However, the latter option needs to be thoroughly explored within the context of environmental regulations of each GCC country.

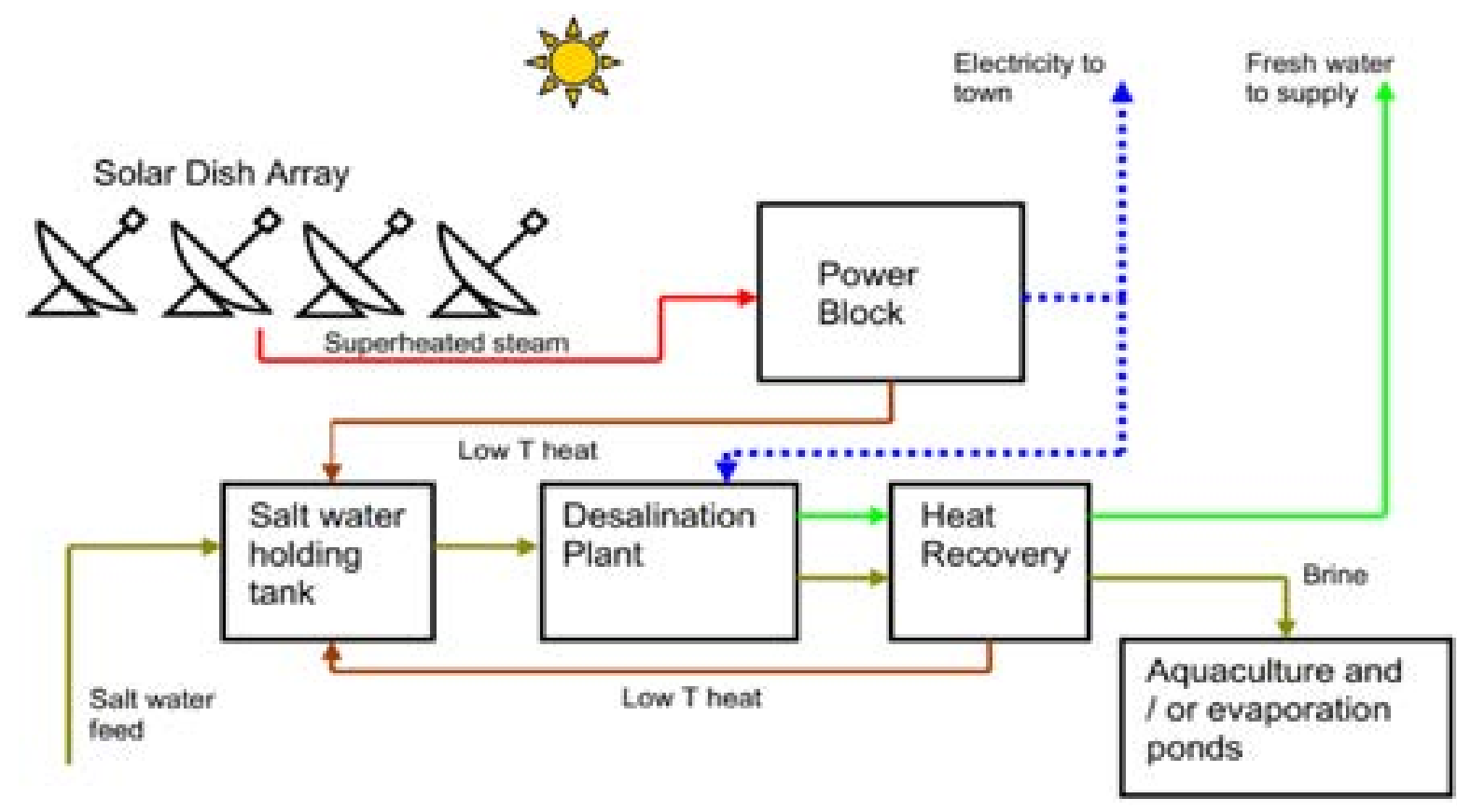

Figure 7. Combined dish-based solar thermal power generation and RO desalination (Burgess and Lovegrove, 2005). 


\section{References}

Ahmed, M., Shayya, W.H., Hoey, D. and Al-Handaly, J. 2002. Brine disposal from inland desalination plants: research needs assessment. Water International. 27:194-201.

Ahmed, M., Al Jabri, S. and Choudri, B.S. 2016. Green challenges and some technological solutions in the water sector of the Gulf Cooperation Council countries. In: M. Abdel Raouf and M. Luomi (ed.) The green economy in the Gulf. Routledge, 2 Park Square, Milton Park, Oxon OX14 4RN, London, UK.

Al Barwani, A. and Helmi, T. 2006. Sea water intrusion in a coastal aquifer: a case study for the area between Seeb and Suwaiq, Sultanate of Oman. Agr. Marine Sci. Res. J. 11:55-69.

Al-Belushi, A. S. 2003. Desertification in Al Batinah Plain, Sultanate of Oman. PhD dissertation, Jordan University, Jordan (in Arabic).

Al-Hallaj, S. Farid, M.M. and Tamimi., A.R. 1998. Solar desalination with a humidification-dehumidification cycle: performance of the unit. Desalination. 120:273-280.

Al Jabri, S., Ahmed, M. and Al Maktoumi, A. and Prathapar, S.A. 2012. Potential of managed aquifer recharge in the Governorate of Muscat, the Sultanate of Oman. In: Hydrogeology in Arid Environments. Hannover, Germany.

Al Jabri, S., Ahmed, M. and Choudri, B.S. 2015. Prospects of desalination for irrigation water in the Sultanate of Oman. J. Water Reuse and Desal. 5:430-436.

Al Khamisi, S., Prathapar, S.A. and Ahmed, M. 2013. Conjunctive use of reclaimed water and groundwater in crop rotations. Ag. Water Mangt. 116: 228-234. doi: 10.1016/j.agwat.2012.07.013.

Bajjali, W. 2003. Evaluation of the groundwater salinity throughout Sultanate of Oman using GIS. Available at: http://williambajjali.azurewebsites.net/Publications.aspx

Bouwer, H. 2002. Artificial recharge of groundwater: hydrogeology and engineering. Hydrogeol. J. 10:121142. doi: 10.1007/s10040-001-0182-4.

Burgess, G. and Lovegrove, K. 2005. Solar thermal powered desalination: membrane versus distillation technologies (online: solar-thermal.anu.edu.au/wpcontent/uploads/DesalANZSES05.pdf) (accessed 14 August 2010).

Burn, S., Hoang, M., Zarzo,D., Olewniak, F., Campos, E., Bolto, B. and Barron, O. 2015. Desalination techniques - A review of the opportunities for desalination in agriculture. Desalination. 364: 2-16. http:// dx.doi.org/10.1016/j.desal.2015.01.041.

Childs, W.D., Dabiri, A.E., Al-Hinai, H.A. and Abdullah, H.A. 1999. VARI-RO solar powered desalting study.
Desalination. 125:155-166.

Choudri, B. S., Al-Busaidi, A. and Ahmed, M. 2013. Climate change, vulnerability and adaptation experiences of farmers in Al-Suwayq Wilayat, Sultanate of Oman. Int. J. Climate Change Strat. Manage. 5:445454.

Economist Intelligence Unit. 2009. "The GCC in 2020: The Gulf and its people". The Economist. http://www. economist.com/

Economist Intelligence Unit. 2010. "The GCC in 2020: Resources for the future". The Economist. http:// www.economist.com/

Elimelech, M., and Philip, W.A. 2011. The future of seawater desalination: energy, technology, and the environment. Science. 333:712-717.

Food and Agriculture Organization (FAO). 2003. Desalination of brackish water and seawater, status in California and the USA by K. Tanji. Draft report, FAO, Rome, Italy.

Food and Agriculture Organization (FAO). 2006. Water desalination for agricultural applications. Land and Water Discussion Paper 5, FAO, Rome, Italy.

GCC statistical bulletin. 2016. GCC statistical bulletin 2014. Muscat, Sultanate of Oman. http://www. gccstat.org/

Goosen, M.F.A., and W. Shayya. 1999. Water management, purification and conservation in arid climates. In: Goosen, M.F.A., and W. Shayya (eds.) Water Management, Purification and Conservation in Arid Climates: Volume I Water Management. Technomic Publishing Co., Lancaster, Pennsylvania, USA.

Goosen M., Sabalani, S.S., Shyya, W. , Paton, C. and Al-Hinai, H. 2000. Thermodynamic and Economic Considerations in Solar Desalination. Desalination. 129: 63-89.

Goosen, M.F.A., Mahmoudi, H. and Ghaffour, N. 2010. Water desalination using geothermal Energy. Energies. 3: 1423-1442.

Goosen, M., Mahmoudi,H. , Ghaffour, N. and Sbalani, S.S. 2011. Application of renewable energies for water desalination. In Schorr, M.: Desalination, trends and technologies. InTech publishing Inc. Rijeka, Croatia.

Hydration Technologies. 2003. Osmatic Water Purification Devices - Osmotic White Paperfrom www. Hydrationtech.com

IPCC. 2007a. Climate Change 2007: Impacts, Adaptation and Vulnerability. Contribution of Working Group II to the Fourth Assessment Report of the IPCC. Cambridge, UK: Cambridge University Press.

IPCC. 2007b. Climate Change 2007: The Scientific Basis, Summary for Policymakers. Contribution of Working Group I to the Fourth Assessment Report of the 
IPCC. Cambridge, UK: Cambridge University Press.

IPCC. 2014. Climate Change 2014: Impacts, Adaptation and Vulnerability. Cambridge, UK and New York: Cambridge University Press.

Lattemann, S., Kennedy, M.D., Schippers, J.C. and Amy, G. 2010. Sustainable water for the future: water recycling versus desalination. Sustain. Water Future 2: 7-39.

Kalogirou, S. 2005. Seawater desalination using renewable energy sources. Progress in Energy and Combustion. Science. 31:2 42-281

Mahmoudi, H., Abdul-Wahab, S.A., Goosen, M.F.A., Sablani, S.S., Perret, J. and Ouagued, A. 2008. Weather data and analysis of hybrid photovoltaic-wind power generation systems adapted to a seawater greenhouse desalination unit designed for arid coastal countries, Desalination. 222: 119-27.

Mahmoudi, H., Spahis, N., Goosen, M.F.A., Ghaffour, N., Drouiche, N. and Ouagued A. 2010. Application of geothermal energy for heating and fresh water production in a brackish water greenhouse desalination unit: A case study from Algeria, J. Renew Sustain Energy Rev. 14: 512-517.

Oxford Economics. 2015. http://www.oxfordeconomics. com.

Price waterhouse Coopers $(\mathrm{PwC}) .2014$. Achieving a Sustainable Water Sector in the GCC: Managing Supply and Demand, Building Institutions, by Tarek El Sayed and Johnny Ayoub.
Serpen, U., Aksoy, N. and Öngür, T. 2010. Present status of geothermal energy in Turkey, Proceedings of Thirty-Fifth Workshop on Geothermal Reservoir Engineering, Stanford University, Stanford, California, 1-3 February SGP-TR-188.

Shaffer, D.L., Yip, N.Y., Gilron, J. and Elimelech, M. 2012 Seawater desalination for agriculture by integrated forward and reverse osmosis: improved product water quality for potentially less energy. J. Membrane Sci. 415-416: 1-8.

Tofigh, A.A., and Najafpour, G.D. 2012. Technical and economical evaluation of desalination processes for potable water from seawater, Middle East J. Sci. Res. 12.

Wright, J.D. 1982. Selection of a working fluid for an organic Rankine cycle coupled to a salt-gradient solar pond by direct-contact heat exchange, J. Sol. Energy Eng. 104: 286-293.

World Bank. 2005. A Water Sector Assessment Report on the Countries of the Cooperation Council of the Arab States of the Gulf. Report No. 32539-MNA.

Zarzo, D., Campos, E. and Terrero, P. 2012 Spanish experience in desalination for agriculture. Desalin. Water Treat. 51: 53-66.

Zekri, S. 2009. Controlling groundwater pumping online. J. Environ. Mang. 90:3581-3588. doi:10.1016/j. jenvman.2009.06.019. 